2. To: (Receiving Organization) WHC, WESF Baseline Control

5. Proj./Prog./Dept./Div.:

WM, WESF

8. Originator Remarks:

Concrete Nondestructive Testing conducted in 1982 by

Construction Technology Laboratories, division of Portland Cement Association.

11. Receiver Remarks: 11A. Design Basel ine Document? [] Yes [X] No
3. From: (Originating organization) WHC, TWRS Equipment Engineering

6. Design Authority/ Design Agent/Cog. Engr.:

F. R. Vollert 


\section{Concrete Nondestructive Tests Conducted in 225-B Building}

F. R. Vollert

Westinghouse Hanford Company, Richland, WA 99352

U.S. Department of Energy Contract DE-AC06-87RL10930

EDT/ECN: 618830

Org Code: $74 \mathrm{~F} 10$

UC: 20010

B\&R Code: EW3135090

Total Pages: 19

Key Words: Reinforced Concrete, Sonic Nondestructive Testing,

Abstract: In 1982, Construction Technology Laboratories (CTL), Portland Cement Association conducted additional sonic concrete nondestructive testing (NDT) in the Service Gallery on the south process (hot) cell walls and adjacent floor slab, including the locations where significant concrete degradation had been found by the 1981 sonic NDT. In the ceiling slabs, the anchor areas for the monorail hangers, and some visible cracks were sonic NDT inspected.

CTL concluded that the hot cell walls have no significant reduction of structural capacity due to concrete degradation. Epoxy injection repairs were recommended by CTL for the damaged anchor areas and through depth cracks in the reinforced concrete ceiling slabs. When completed, the epoxy repairs should be inspected and confirmed with follow on sonic NDT. Lateral bracing for the nonorail system is also recommended to relieve the lateral loads on the hangers.

TRADEMARK DISCLAIMER. Reference herein to ary specific comercial product, process, or service by trade name, trademark, manufacturer, or otherwise, does not necissarily constitute or imply its endorsement, recormendation, or favoring by the United States Givernment or any agency thereof or its contractors or subcontractors.

Printed in the United States of America. To obtain copies of th is document, contact: WHC/BCS Document Control Services, P.O. Box 1970, Mailstop H6-08, Richland WA 99352, Phone (509) 372-2420; Fax (509) $376-4989$.
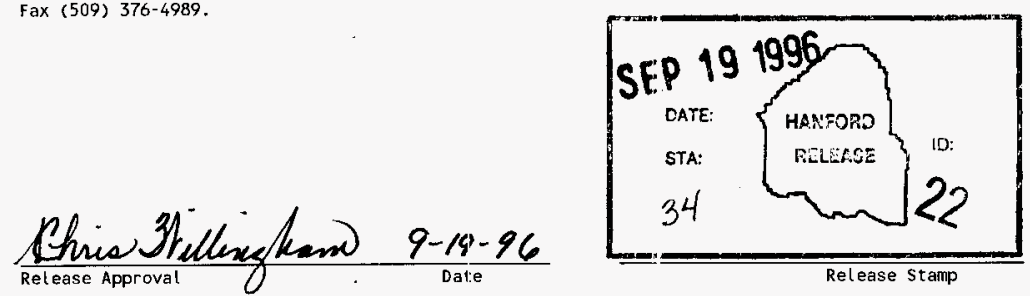

Release \$tamp

\section{Approved for Public Release}


WHC-SD-WM-ER-567 Rev. 0

CONCRETE NONDEISTRUCTIVE TESTS

CONDUCTED IN 225-B BUILDING

WESTINGHOUSE HANFORD COMPANY

September 1996

For the U.S. Department of Energy Contract DE-AC06-87RL10930 
WHC-SD-WM-ER-567 Rev. 0

This page intentionally left blank. 


\section{WHC-SD-WM-ER-567 Rev. 0 \\ CONTENTS}

1.0 HIGHLIGHTS . . . . . . . . . . . . . . . . . . . . . . . . . . . . 1

2.0 TEST PROCEDURE AND EQUIPMENT . . . . . . . . . . . . . . . . . . . . . . . 3

3.0 OPERATING GALLERY CEILING TESTS . . . . . . . . . . . . . . . . . . . . . 6

4.0 COLD MANIPULATOR SHOP CEILING TESTS . . . . . . . . . . . . . . . . . . . . . 7

5.0 HOT MANIPULATOR SHOP CEILING TESTS . . . . . . . . . . . . . . . . . 9

6.0 SERVICE GALLERY FLOOR AND WALL TESTS . . . . . . . . . . . . . . . . 10

7.0 SERVICE GALleRY CEILING TESTS . . . . . . . . . . . . . . . . . . . . 11

8.0 SUMMARY . . . . . . . . . . . . . . . . . . . . . . . . . . 11

9.0 REFERENCES . . . . . . . . . . . . . . . . . . . . . . . . . . . . 14

\section{LIST OF FIGUREB}

1. Wave Path Using Angle Transducer . . . . . . . . . . . . . . . . . 8 
WHC-SD-WM-IR-567 Rev. 0

This page intent:onally left blank. 
WHC-SD-WM-ER-567 Rev. 0

\section{PRELIMINARY REPORT}

\section{CONCRETE NONDESTRUCTIVE TESTS CONDUCTED IN 225-B BUILDING}

by

Melvin S. Abrams and Richard A. Muenow

\subsection{HIGHLIGHTS}

This report summarizes details and results of a sonic nondestructive test (NDT) program conducted in the 225-B Builaing for Rockwell Hanford Operations (Rockwell:, Richland, Washington.

Concrete of the ceiling of the operating gallery, the ceiling of the service gallery, the ceiling of the cold manipulator shop, and the ceiling of the hot manipulator shop was tested. Also tested was the concrete of the south wall of the hot cells in the service gallery and the floor adjacent to the wall. These tests were authorized by Rockwell International Corporation's Service Agreement SA-498, Prime Contract No. DE-AC06-77RL01030 dated July 12,1982 .

Approximately 830 nondestructive tests were conducted during July 13, 14, 15, and 16, 1982. Ceilings in the operating gallery, the service gallery, the cold manipulator shop, and the hot manipulator shop are normal-density concrete. The floor in the service gallery is also normal-density concrete. Hot-cell walls in the service gallery are high-dersity concrete.

The test program was conducted by Melvin S. Abrams, Director, Fire Research Department, Construction Technology Laboratories (CTL), a division of the Portland Cement Association and Richard A. Muenow, a Portland Cement Association Associate. 
All anchor areas of the monorail hangers in the ceiling of the operating gallery were tested. Many of the anchor areas, particularly at locations where the monoril curves toward the hot-cell wall, contained microcracking to a depth ranging from $3 / 4$ to about $2-1 / 2$ in. from the bottom, top, or both surfaces of the ceiling slab.

Concrete at anchor locations where the monorail tracks curve also had cracks parallel to the surface oE the ceiling at several locations through the ceiling depth. In the anchor area locations, less concrete damage was detected Eor the hangers supporting the straight runs of the monorail than for those supporting curved sections of the monorail tracks.

Two large cracks are visible in the zeiling of the operating gallery. Both cracks were reported to leak water from the second floor of the building. This indicates a continuous path through the depth of the ceiling. Crack continuity through the depth of the ceiling was corroborated by NDT tests.

All anchor areas in the ceiling of the cold manipulator shop were tested. Microcracking ard cracking of the concrete in several locations were detected. A crack, running from east to west, was observed in the ceiling adjacent to a line of anchors. This crack cuts across the anchor Iine about 4 to 6 in. from the bottom surface of the ceiling.

The ceiling of the hot manipulator shop was tested from the second floor. Microcracks and cracks in the anchor areas of some of the monorail hangers were detected. 
WHC-SD-WM-ER-567 Rev. 0

Tests conducted in the service gallery on the south wall of the hot cells and the floor adjacent to the wall were made at locations previously tested. $(1,2)$ Little change in the condition of the concrete was detected with the exception of the area at E-Cell where an existing radiation leak is located. Some extension of the previously detected damage to the concrete in the wall and the floor adjacent to the radiation leak was noted. The ceiling of the service gallery was tested from the service canyon side. Few discontinuities were detected in the ceiling. A large crack, running the width of the service gallery near the east end of D-Cell, was noted. This crack appears to be an extension of the crack observed in the ceiling of the operating galiery at the same location. The crack in the ceiling of the service gallery is perpendicular to the stifaces of the ceiling. To avoid extension of damage to the concrete in the anchor areas, epoxy injection repair procedures should be initiated as quickly as possible. Lateral bracing of the monorail system should also be installed at the earliest spportunity. A complete evaluation of the structural capacity of the anchor system to determine its ability to carry the design loads should be made.

\subsection{TEST PROCEDURE AND EQUIPMENT}

The nondestructive testing (NDT) used is a pulse-echo microseismic technique. A device is used to transmit a mechanical, low-Erequency stress wave into the concrete from the outside floor or wall. Wave energy reflections occur at 
discontinuities within the wall, and at the inside or back surface of the wall. All reflections are measured with a transducer positioned on the concrete surface. Signals are recorded by an oscilloscope. Data recorded include time between reflections, frequency of reflections, attentuation, absorption, and decay time for the wave energy.

Conditions of concrete such as compressive strength, modulus of elasticity, Poisson's Ratio, voiding, honeycombing, cracking, loss of cement matrix and loss of bond to aggregate can be calculated and identified using NDn data. Subsequently, structural integrity of the concrete member can be evaluated using this information.

Test equipment used for the program has been developed in recent years for the unique purpose of inspecting concrete from one side. The equipment is not wholly available comercially. Most other concrete nondestructive equipment uses throughtransmission technigues that require access to both sides of a structure. This NDT equipment and procedure are significantly different from those used in NDT of metals. The equipment has been used extensively to determine, by NDT, concrete properties for the corps of Engineers, Nuclear Regulatory Commission, Bureau of Reclamation, Department of Transportation, utility companies, and engineering firms.

To accomplish the 225-B NDT program and analysis, the following equipment was used: 
(a) Oscilloscope with extensive modifications to the electronics

(b) Piezoelectric Transducer with wave shaping, filtering, and rejection capabilities

(c) Coaxial cables

(d) Camera

(e) Assorted Adapters The step-by-step procedure is ats follows:

(a) Interconnect all equipment with ccaxial cable.

(b) Calibration of electronics in accordance with manufacturer's instructions.

(c) Select a test area in the concrete structure without deterioration; perform base-line tests as outlined in Steps (f) to (1).

(d) Set oscilloscope controls for calculating time interval and amplitude gain using base-line test data.

(e) Select test locations in the concrete structure with suspected deterioration; locate and number them from a permanent reference point.

(f) Place Piezoelectric Transducer at test location on the concrete surface; apply a thin layer of couplant to transducer face to assure a contiruous path from face to concrete surface.

(g) Place mechanical wave producer approximately 1 in. to 2 in. from transducer.

(h) Set oscilloscope for single sweep operation in the storage mode. 
(i) Actuate mechanical wave producer.

(j) Data will appear on cathode ray zube (CRT) of oscilloscope.

(k) Repeat step (i) as required to bilid image intensity.

(1) Make initial interpretation of data from presentation of image in terms of time, frequency, and decay rate.

(m) Swing camera into place and photograph the CRT image.

(n) Erase data from CRT of oscilloscope.

(o) Proceed to next test location.

\subsection{OPERATING GALLERY TESTS}

Three-hundred and one nondestructive tests were conducted on the ceiling of the operating gallery. All anchor areas of the monorail hangers were tested. Also, two major cracks, one located near $\mathrm{D}$ Cell and the other near $\mathrm{AH}$ Cell were mapped. These cracks generally run from north to south across the ceiling of the operating gallery.

Microcracking and cracks parallel to the surface of the ceiling were detected at many of the anchor areas of the monorail hangers. Originally the concrete was microcracked in these areas by the action of the rotary-inpacting drill used during the installation of the anchors. This original microcracking increased and, in some cases connected up and formed horizontal cracks, due to the movement of the manipulators on the monorail. The most extensive damage was noted in the area where the monorail curves. As the manipulators move across this area, horizontal forces on the hangers are produced 
WHC-SD-WM-] $]$ R-567 Rev. 0

causing stresses in the lateral direction at the anchor area. the least damage was observed on the straight runs of the monorail.

The two large cracks observed near $D$ Cell and $A H$ Cell were mapped using a 45 degree angle transducer. By placing the transducer on the ceiling surface at selected distances from the crack, it was possible to check the continuity and location of the crack within the ceiling the same distance up from the bottom surface of the ceiling. For example, if the transducer was placed on the ceiling 1 in. from the crack, it was possible to observe the crack 1 in. up from the ceiling surface. If the transducer was placed 4 in. frcm the crack, the signal received by the transducer would be for the concrete at the location of the crack 4 in. up from the bottom surface of the ceiling, as shown in Fig. 1 .

It was reported that water leaked through both cracks from the floor above. the continuity of the cracks through the ceiling was corroborated by the: nondestructive tests. Generaliy, the cracks were perpenclicular to the surfaces of the ceiling. The most severely damaged concrete in the anchor areas of the monorail hangers and the cracks in the ceiling of the operating gallery should be repaired using epoxy injection techniques. This should be done as expeditiously as possible.

\subsection{COLD MANIPULATOR SHOP CEIIING}

Thirty-one nondestructive tests were conducted at the monorail hanger anchor locations in the ceiling of the cold manipulator shop. One hundred fourty-four tests were conducted 
WHC-SD-WM-ER-567 Rev. 0

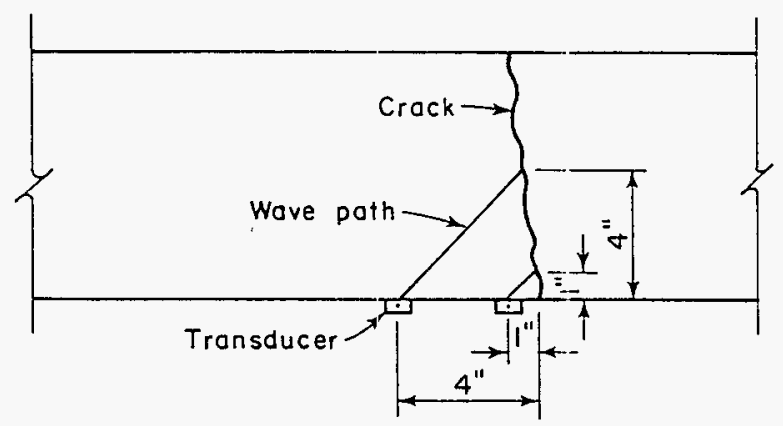

Fig. 1 Wave Path Using Angle Transducer 
while mapping cracks in the ceiling. Several of the anchor locations were microcracked to distances extending about $2-1 / 2$ in. from the bottom surface, top sisface, or both surfaces of the ceiling. At several locations, light multiple cracking was also observed to about $2-1 / 2$ in. from the bottom surface of the ceiling.

The large crack running from east to west that is adjacent to an anchor Iine, was mapped using the 45 degree angle transducer. Over most of its length, the crack is continuous through the depth of the ceiling. The crack is purpendicular to the bottom face of the ceiling for a distance of about 4 in. Above 4 in., the crack turns and crosses the anrhor line. In the top 3 in. of the ceiling, the crack is perpendicular again to the surfaces of the ceiling.

The crack crossing the anchor line presents a potentially dangerous condition at that location. Epoxy injection repairs should be accomplished as quickly as possible.

\subsection{HOT MANIPULATOR ROOM CEIIING}

Since it was not possible to test the ceiling of the hot manipulator shop from the underside, it was tested from the second floor. To cover all of the anchor areas of the monorail hangers, 39 tests were conducted on a grid pattern 2 ft on centers.

Microcracking extending to a depth of about $1-1 / 2$ in. on the bottom side of the ceilinc and to about $3 / 4$ in. on the top side of the ceiling was observed. Horizontal cracks in the 
bottom half of the ceiling were also noted. Damage to anchor areas in the hot manipulator ceiling was less extensive than observed in either the operating gallery ceiling or the cold manipulator shop ceiling. No major vertical cracks were observed in the hot manipulator room ceiling.

\subsection{SERVICE GALLERY WALL AND F'LOOR}

Tests conducted during the two previous inspections on the hot-cell wall and adjacent floor area were repeated. $(1,2)$ In addition, a few additional nondestructive tests were made in the area of the existing radiation leak outside of E CelI. The radiation leak was previously detected by Hanford personnel. In aIl, 165 tests were conducted.

Condition of the concrete in the floor adjacent to the wall showed little change from the previous inspections. Although much of the concrete in the cell walls showed little change in condition from previous inspections, some areas on the cell side of the wall showed some delamination about $1 / 2$ in. from the concrete surface.

An extension of the damage in the radiation-leak area, near $E$ Cell was also noted. Damage to thet concrete is progressing further out from the cell side face of the wall toward the service gallery side of the wall. Also, the depth of the damage has extended upward in the wall to a distance of about 5 or 6 in. at the center of the leak area and tapers off to about $3 \mathrm{in}$. at $2-1 / 2$ ft on either side of the center of the leak area. The additional damage at this point poses no structural problems concerning the stability of the wall. 


$$
\text { WHC-SD-WM-ER-567 Rev. } 0
$$

\subsection{SERVICE GALLERY CEILING}

Due to the pipes and other obstructions anchored to the ceiling of the gallery, the nondestructive test program was conoucted from the canyon side on the second sloor. A total of 149 tests were conducted on approximately a 2-ft grid pattern for the entire length and width of the canyon floor. Microcracking extending to a depth of about $1-1 / 4 \mathrm{in}$. was detected on both faces of the ceiling at several locations. Some horizontal cracking was also observed near the bottom side of the ceiling. Generally, the concrete in the service gallery ceiling was in very good condition.

The crack observed running from north to south in the vicinity of $\mathrm{D}$ cell was mapped using a 45 degree angle transducer. In most locations, the crack was continuous through the slab depth and perpendicular, with minor deviations, to the surfaces of the slab. Epoxy injection repairs should be made at the crack locations to prevent leaking.

\subsection{SUMMARY}

Approximately 830 nondestructive tests were conducted on the ceiling of the operating gallery, the ceiling of the service gallery, the ceiling of the hot manifulator shop, the ceiling of the cold manipulator shop, the hot-cell walls in the service gallery and the floor adjacent to the walls. Microcracks and cracks in anchor areas of the moncrail hangers were detected at about 50 locations in the operating gallery, hot manipulator shop, and cold manipulator shop ceilings. The 
WHC-SD-WM-ER-567 Rev. 0

worst damage was detected in locations where the monorail curves toward the hot cells in the operating gallery.

Large cracks were detected in the operating gallery, cold manipulator shop, and service gallery ceilings. These cracks are continuous through the depth of the slabs for most of their lengths. The crack in the cold manipulator shop ceiling cuts across one of the anchor lines and presents a potentially dangerous condition.

Some damage to the anchor areas of the monorail hangers in the hot manipulator shop was observed.

Concrete in the hot-cell walls and the floor adjacent to them in the service galiery showed little change from the previous inspection, except in the area of: the radiation leak at $\mathrm{E}$ Cell. $(1,2)$ Additional damage was noted at the radiation leak location. Damage to the concrete has progressed further out than previously observed from the hot cell side toward the service gallery side. The heicht of damage in the wall above the construction joint between the wall ard the floor has also increased beyond the condition previously detected . However, the additional damage does not pose any structural problems concerning capacity of the walls to carry the load.

Concrete in the ceiling of: the service gallery generally was in good condition.

Based on results of the test program, the following recommendations are made:

(a) Manipulators should be moved slowly over the monorail system, particularly where the tracks curve.

(b) Lateral bracing for the monorail system should be controlled.as quickly as possiblt: 
WHC-SD-WM-ER-567 Rev. 0

(c) The crack in the ceiling of the cold manipulator shop should be monitored carefully. Additional widening of the crack or flaking of concrete from the edges of the crack may indicate a worsening condition in this area.

(d) Repairs to about 50 anchor areas of the monorail hangers and to the cracks in the ceiling should be made immediately by use of epoxy injection techniques.

(e) Shortly after the epoxy repairs are completed, all repaired areas should be subjected to a nondestructive test program to ensure that all izracks have been filled with epoxy.

(f) A complete evaluation of the strictural capacity of the anchor should be made to determine its ability to carry design loads without additional structural repairs. 


$$
\text { WHC-SD-WM-IER-567 Rev. } 0
$$

\subsection{REFERENCES}

1. Abrams, M.S. and Muenow, R.A., Nondestructive Tests of Reinforced Concrete in 225-B Building Construction Technology Laboratories, a Division of the portland Cement Association, Skokie, IL (April, 1981).

2. Abrams, M.S. and Muenow, R.A., Nondestructive Tests of Reinforced Concrete in 225-B Building Construction Technology Laboratories, a Divisisn of the Portland Cement Association, Skokie, IL (November, 1981). 